\title{
Biodiesel Synthesis from African Pear (Dacryodes edulis) Oil Using Catalyst Assisted Transesterification Process
}

\author{
Akpan Uwem Isong ${ }^{1}$, Akpabio Ukana Davies ${ }^{1}$, Owhoeke Elechi ${ }^{2, *}$, Ekpo Idongesit Effiong ${ }^{2}$ \\ ${ }^{1}$ Department of Chemistry, University of Uyo, Uyo, Nigeria \\ ${ }^{2}$ Department of Pure and Industrial Chemistry, University of Port Harcourt, Port Harcourt, Nigeria
}

\section{Email address:}

elechiowhoeke@yahoo.com (O. Elechi)

\section{To cite this article:}

Akpan Uwem Isong, Akpabio Ukana Davies, Owhoeke Elechi, Ekpo Idongesit Effiong. Biodiesel Synthesis from African Pear (Dacryodes edulis) Oil Using Catalyst Assisted Transesterification Process. World Journal of Applied Chemistry. Vol. 5, No. 4, 2020 , pp. 65-69. doi: $10.11648 /$ j.wjac.20200504.12

Received: December 15, 2020; Accepted: December 29, 2020; Published: January 18, 2021

\begin{abstract}
This study examines the synthesis of biodiesel from African pear oil using catalyst assisted transesterification (One-step) process. The D. edulis used in this study were obtained from Port Harcourt City Local Government Area of Rivers State, Nigeria. The pulp oil was extracted and subjected to physicochemical analysis and gas chromatography was used to check the free fatty acid content. The yield of the oil was $47 \%$ which is highly significant. Gas-chromatographic analysis of the oil extract showed free fatty acid content as palmitic acid $26.41 \%$, stearic acid $24.56 \%$, oleic acid $2.20 \%$ and others $46.83 \%$ for the pulp. The physicochemical parameter of synthesized oil revealed density; $0.98 \pm 6.01 \mathrm{mg} / \mathrm{dm}^{3}$, saponification number; $199.16 \pm 6.09 \mathrm{mgKOH} / \mathrm{g}$, acid number; $1.85 \pm 0.08 \mathrm{mgKOH} / \mathrm{g}$, iodine number; $74.98 \pm 2.83$ wijs, and peroxide value; $11.80 \pm$ $0.29 \mathrm{mEq} / \mathrm{kg}$. The African pear showed almost same level of saturation and unsaturation. Biodiesel yield of the pulp oil attained optimum yield of $87 \%$ at the oil/methanol molar ratio of $1: 6$ and temperature of $60^{\circ} \mathrm{C}$. The properties of the produced biodiesel were specific gravity $0.89 \pm 0.12$, kinematic viscosity was $2.80 \pm 0.14 \mathrm{~mm}^{2} / \mathrm{s}$, water and sediment $0.020 \pm 0.0021 \%$, the acid number was $0.15 \pm 0.020 \mathrm{mgKOH} / \mathrm{g}$, cetane number 63 , pour point $-13^{\circ} \mathrm{C}$, flash point $137^{\circ} \mathrm{C}$ and sulphur contents $0.02 \% \mathrm{~m} / \mathrm{m}$. These values were within standards for petrodiesel. It therefore shows that the D. edulis oil could serve as a good source of feedstock for biodiesel synthesis.
\end{abstract}

Keywords: Biodiesel, African Pear, Free Fatty Acid, Transesterification, Physicochemical Properties

\section{Introduction}

The use of fossil fuels have been on since the industrial revolution in Europe, as they were the cheapest and easily available source of energy and the world depended on it to service its economy. Fossil fuels are made from dead organic matters which were subjected to intense heat and pressure over a long period of time; petroleum, coal and natural gas are the major examples of fossil fuels [1]. Due to the environmental issues associated with fossil fuels, energy sourced from Biomass has been investigated to have the capacity to eliminate these environmental issues. Biomass can be used for energy in several ways; such as the conversion into liquid and gaseous fuel like ethanol and biodiesel respectively, for use in domestic and industrial generation of energy as well as in mobile source combustion [2].

Transesterification process could be used to produce biodiesel from biomass, it is the process of converting the fatty acids from their glycerol backbone to form fatty acid ester (FAE) [3]. Fatty acid esters commonly known as biodiesel can be produced through the batch or continuous process by transesterifying triglycerides such as animal fat or vegetable oil with lower molecular weight alcohols in the presence of an alkali or acid catalyst. This is a typical reaction that occurs step wisely, resulting in the formation of monoglycerides and diglycerides as intermediate. Equation of the transesterification procedure of biodiesel is shown below.

$$
\mathrm{RCOOR}{ }^{\prime}+\mathrm{R} ’ \mathrm{OH} \leftrightarrow \mathrm{R} \mathrm{R}^{\prime} \mathrm{OH}+\mathrm{RCOOR} ”
$$

It is a transesterification reaction where RCOOR' is the ester, R"OH and R'OH are alcohol, RCOOR" an ester mixture. Using methanol as the alcohol in the transesterification process, it gives a mixture of methyl ester, 
similarly using ethanol gives a mixture of ethyl esters. In both cases, glycerine will be the co-product of the reaction. The large vegetable oil molecule is reduced by one-third

$$
\left.\right|_{\mathrm{H}_{2} \mathrm{C}-\mathrm{O}-\stackrel{\mathrm{I}}{\mathrm{C}}-\mathrm{R}_{3}} ^{\mathrm{HC}-\mathrm{O}-\stackrel{\mathrm{C}}{\mathrm{C}}-\mathrm{R}_{2}}+3 \mathrm{CH}_{3} \mathrm{OH} \longrightarrow
$$

The most significant process in biodiesel synthesis is esterification because it is a precursor to the mixture of esters, though other steps are required to attain a final product that conforms with international standards [4]. After the formation of the product, what follows is purification which reduces the number of contaminants to acceptable levels; these include the removal of a catalyst, water, methanol, and glycerides.

Transesterification process limits the high viscosity of oils and fats. The use of $\mathrm{NaOH}$ in the catalysis of the transesterification reaction is preferred over acid because it is faster [4]. The viscosity of esters is generally low compared to that of the corresponding fats and oils. The esters play a vital role on the injection process and ensure better atomization of the fuel in the internal combustion engine. The effect of the possible polymerization reaction is also decreased. The aforementioned reasons make methyl esters good precursor for biodiesel production. The use of natural oil in the synthesis of biodiesel is a huge breakthrough due to its economic, environmental, political and scientific importance. The use of biodiesel as alternative to petro-diesel stands to settle many issues which include increasing energy price, increasing need of energy imports, reduction of the rate of fossil fuel combustion and the security of energy supply for many countries. Fuels from plant products are useful in compression ignition engines, either used as stand-alone fuels or blended with petro-diesel [5].

The main objective of the study is to modify oils extracted from the pulp of Dacryodes edulis into biodiesel.

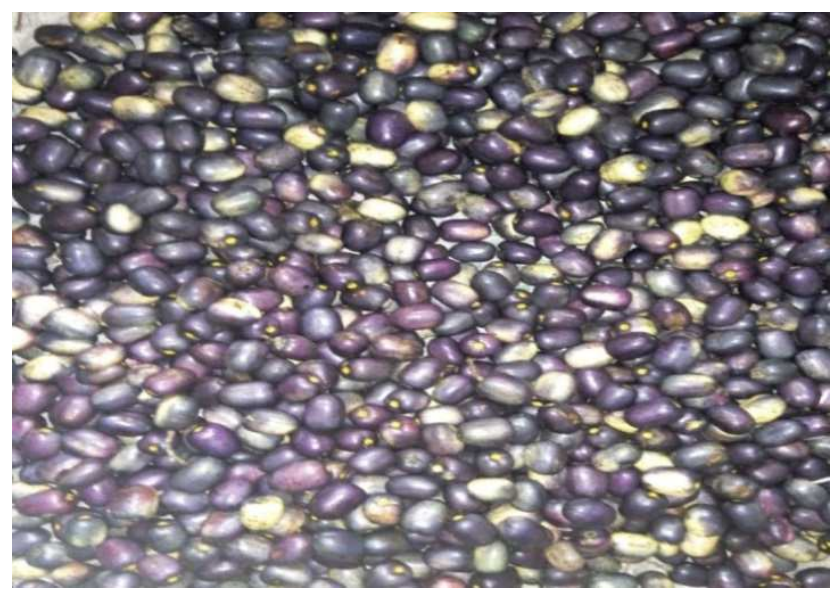

Figure 1. African pear.
$(1 / 3)$ its original size, lowering the viscosity, making it similar to petrodiesel fuel in performance. The reaction produces three molecules of an ester from one molecule.

$\mathrm{H}_{3} \mathrm{C}-\mathrm{O}-\stackrel{\mathrm{O}}{\mathrm{C}}-\mathrm{R}_{1}$

\section{Methodology}

\subsection{Sample Collection and Preparation}

D. edulis pulp used in this study were obtained from Port Harcourt City Local Government Area of Rivers State, Nigeria. The fruits were dehulled, and the seed separated from the fruit. Sun-dried for ten (10) days and finally milled to a fine powder in a milling machine, then stored in an airtight container at room temperature.

\subsection{Extraction of Oil}

One hundred grams $(100 \mathrm{~g})$ of the powdered D. edulis was wrapped with Whatman filter paper and transferred into the thimble of a Soxhlet extractor. The thimble was carefully fixed on a 1 L capacity round-bottomed flask, seven hundred millilitres $(700 \mathrm{ml})$ of n-hexane (b.p. $40-60^{\circ} \mathrm{C}$ ) was poured into the flask and heated at $60^{\circ} \mathrm{C}$ with a thermostatically controlled heating mantle and allowed to reflux continuously for 6 hours [4]. Percentage of oil yield was determined as expressed below.

$$
\% \text { Oil content }=\frac{\mathrm{Wo}}{\mathrm{Ws}} \ldots
$$

Where Wo = weight of the oil extracted, Ws $=$ weight of the sample. The Dacryodes edulis oil was examined for free fatty acid according to method of the American Oil Chemical Society (AOCS) standard which requires the use of a waxtype capillary column and $\mathrm{C}_{23}$ as an internal standard. Also, the chemical parameters of the pulp oil were tested using the standards of "American Society for Testing and Materials" (ASTM) and those described by Mehlenbacher [6].

\subsection{Synthesis of Biodiesel}

The biodiesel was synthesized using transesterification reaction. $10 \mathrm{ml}$ of the oil sample was measured and poured into five (5) different conical flasks and heated for 1 hour from $0^{\circ} \mathrm{C}$ to $60^{\circ} \mathrm{C} .1 \% \mathrm{NaOH}$ (aq) was added to $40 \mathrm{ml}, 50 \mathrm{ml}, 60 \mathrm{ml}, 70$ $\mathrm{ml}$ and $80 \mathrm{ml}$ measured methanol to prepare the sodium methoxide, which was slowly transferred into the five (5) labelled conical flasks containing $10 \mathrm{ml}$ of the oil and heated to $40^{\circ} \mathrm{C}$ and spinned for 1hour and allowed to settle for 24 hours in a separating funnel, which gave oil/alcohol ratio of 1:4, 1:5, 1:6, 1:7, and 1:8 respectively. This same experimental set-up was repeated at temperatures of $50^{\circ} \mathrm{C}$ and $60^{\circ} \mathrm{C}$. At the end of the reaction, the reaction mixture was separated into two phases; fatty acid methyl ester (FAME) and the lower 
glycerine. The FAME was decanted out. The biodiesel produced was purified by first washing with acidified water to neutralize the mixture of ester followed by washing with water only to remove the remains of methanol, catalyst; as they are water soluble substances. The product obtained was finally dried to remove traces of water [4]. The synthesized biodiesel properties tested was based on standard procedures as described by Thushari and Babel [7].

$$
\% \text { Yield of Biodiesel }=\frac{\text { Vol. of Biodiesel Produced }}{\text { Vol.of the Oil transesterified }} \times 100 \ldots
$$

\section{Results and Discussions}

\subsection{Free Fatty Acid and Physicochemical Parameter}

The result of free fatty acid and the physicochemical parameters of the Oil obtained from the pulp of African pear are presented in Tables 1 and 2.

Table 1. Fatty Acid Assay of the oils from African pear pulp

\begin{tabular}{llll}
\hline Fatty Acid & Name & Formula & Amount in\% \\
\hline Palmitic & Hexadecanoic & $\mathrm{C}_{16} \mathrm{H}_{32} \mathrm{O}_{2}$ & 26.41 \\
Stearic & Octadecanoic & $\mathrm{C}_{18} \mathrm{H}_{36} \mathrm{O}_{2}$ & 24.56 \\
Oleic & Lionoleic & $\mathrm{C}_{18} \mathrm{H}_{32} \mathrm{O}_{2}$ & 2.20 \\
Others & Other FA & $\mathrm{C}_{20}$ to $\mathrm{C}_{24}$ & 46.83 \\
\hline
\end{tabular}

The oil extraction process showed that the percentage yield from the pulp of African pear was $47 \%$. The yield was higher than the yields reported for some non-edible oilseed like Mangifera Indica, 30.7\% [4] but the same with almond seed oil, 47\% [8]. The observed oil content of pulp of the African pear was lower than some edible oil as reported by Rashid et al. [9], (soybeans; 65\% and cottonseed; $60 \%$ ).

The free fatty acid composition of the African Pear indicated that it comprised 33.6\% saturated acids (palmitic and stearic), $42.4 \%$ and $20.5 \%$ of unsaturated acids oleic and linoleic, and the others (linolenic) was 3.5\%. The Seed oil had $29.22 \%$ of saturated palmitic and stearic acid, while unsaturated Oleic, Linoleic and others (Linolenic) were $45.5 \%, 17.38 \%$ and $7.9 \%$ respectively. These correlated with the reports of Obasi and Okilie, [10] which obtained 61.9\% of the oil from the seed. The oil shows a mixed level of saturation and unsaturation thereby indicating that it is of the Oleic-Linoleic acid group. Also, the fatty acid constituents of the Dacryodes edulis oil were of the same required quality with the fatty acids for synthesis of biodiesel. The quantity and quality of oil produced by the pulp were better than that of the seed, so, this work focused on transesterification of oil from the pulp for biodiesel production.

Table 2. Physicochemical parameters of the Oil from African pear.

\begin{tabular}{ll}
\hline Parameters & African pear \\
\hline Density $\left(\mathrm{g} / \mathrm{dm}^{3}\right)$ & $0.98 \pm 0.08$ \\
Saponification Number $(\mathrm{mgKOH} / \mathrm{g})$ & $199.16 \pm 6.09$ \\
Acid Number $(\mathrm{mgKOH} / \mathrm{g})$ & $1.85 \pm 0.08$ \\
Iodine Number $(\mathrm{wijs})$ & $74.98 \pm 2.83$ \\
Peroxide Value $(\mathrm{mEq} / \mathrm{Kg})$ & $11.80 \pm 0.29$ \\
\hline
\end{tabular}

Each data is a mean of three replicate determination \pm SD
The physicochemical properties of the oil from the African pear pulp are shown in table 2 above. Saponification value of $199.16 \pm 6.09 \mathrm{mgKOH} / \mathrm{g}$ suggests a high concentration of triglycerides. This value does not agree with those of saturated fatty acids rich oils in plants such as Cocos nucifera coconut (248-265 mgKOH/g of oil) and Elais guineensis, palm kernel oils (230-254 mg KOH/g of oil) [11]. Pearson [12], posited that oil with higher saponification values contains a high proportion of lower fatty acids. Therefore, the values obtained for $D$. edulis oils in this study show that they contain high amounts of higher fatty acids. The oil has a low acid number of $1.85 \pm 0.08 \mathrm{mgKOH} / \mathrm{g}$, this represents free fatty acid content due to enzymatic activity which was below $5.00 \%$ free fatty acids content recommended as the maximum for non-rancid oil [13]. The Iodine number was $74.98 \pm 2.83$ wijs. The iodine number is a characteristic of the unsaturation of a fatty acid or its esters. Lipids with unsaturated fatty acid (containing one or more double bonds) are easily assimilated and broken down to produce calorific energy than saturated fatty acids. Higher iodine number is an indication of more unsaturated nature of the oil. Nevertheless, a peak of the iodine number causes the stability of the oil drop since it is more likely to experience oxidation. The peroxide value was $11.80 \pm 0.29 \mathrm{mEq} / \mathrm{kg}$ which was closer to reports by Ogunsuyi, [4] on the African pear $(12.34 \pm 0.10 \mathrm{mEq} / \mathrm{kg})$. This correlates with works on Citrullus lanatus oil by N'guetta et al. (12.34 \pm 0.23 and $10.93 \pm 0.47 \mathrm{mEq} / \mathrm{kg})$. The physicochemical property compared favourably with those of other oils like Arachis hypogea [14].

\subsection{Biodiesel from One Step Esterification Process}

The result of the Biodiesel Synthesis and Biodiesel parameters are presented in Tables 3 and 4.

Table 3. Volume (\%) of Biodiesel synthesized at different reactions temperature.

\begin{tabular}{|c|c|c|c|}
\hline Oil/Ac ratio $\quad$ Temp. $\left({ }^{0} \mathrm{C}\right)$ & 40 & 50 & 60 \\
\hline $1: 4$ & 59 & 61 & 64 \\
\hline $1: 5$ & 63 & 67 & 54 \\
\hline $1: 6$ & 82 & 84 & 87 \\
\hline $1: 7$ & 71 & 71 & 73 \\
\hline $1: 8$ & 70 & 73 & 61 \\
\hline
\end{tabular}

The biodiesel yield from the pulp of the African pear oil varied with alcohol increase and change in temperature. The influence of the feed molar ratio on transesterification reaction with the oil was studied using five different molar ratios 1:4, 1:5, 1:6, 1:7 and 1:8 of the alcohol/oil at varying temperatures. The respective yields at each molar ratio are given in Table 3. A steady increase was observed from the lowest molar ratio of 1:4 till 1:6 where it had the optimum yield of $82 \%$ but decreased downward from 1:7 for the temperature of $40^{\circ} \mathrm{C}$, same was observed for the $50^{\circ} \mathrm{C}$ and $60^{\circ} \mathrm{C}$. The progressive yields indicated the positive influence of the alcohol/oil ratio on the transesterification reaction of the seed oil and this observation substantiates the fact that the 
methanol was sufficient to break the glycerine-fatty acid linkages [15]. However, at molar ratios higher than 1.6, the yields began to decline, which showed that further increase beyond the optimized ratio had little or no impact on the ester yield. It should be noted that the highest yield of biodiesel from the oil was $87 \%$ at a temperature of $60^{\circ} \mathrm{C}$. This trend can be explained by the fact that methanol has polar hydroxyl group which act as an emulsifier causing emulsification that made the separation of the ester layer from the water layer very difficult at a high volume of the methanol thus, causing a loss in the yield of the ester [16]. This result is higher than $79 \%$ reported by Ibeto et al. [17] on A. hypogea Oil but similar to $88 \%$ reported by Galadima et al. [18], the yield is also higher than the report of $64.20 \%$ on the African Pear by Ogunsuyi [4]. Ishola et al. had a yield of $62.5 \%$ from palm oil feedstock which is also lower [19]

Table 4. Physicochemical properties of produced Biodiesel from African pear compared with petro diesel and ASTM specifications for diesel fuels.

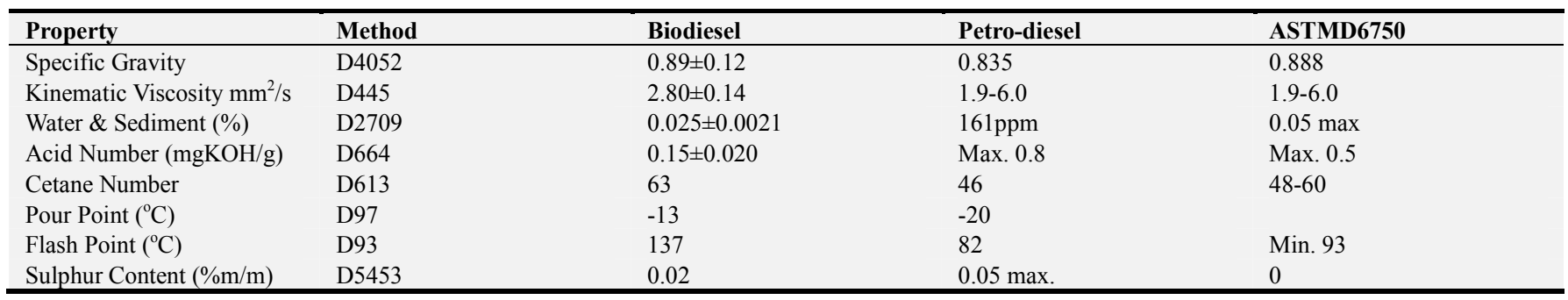

Max. = maximum Min. = Minimum

Table 5. Properties of selected biodiesels synthesized from different fruits of other works.

\begin{tabular}{|c|c|c|c|c|}
\hline Type of Biodiesel & Kinematic Vis. & Iodine No. & Cetane No. & Saponification No. \\
\hline This work & 2.80 & 76.98 & 63 & 198.16 \\
\hline Palm Oil & $4.42-4.76$ & $35-61$ & $59.9-62.8$ & $186-209$ \\
\hline Soybean & $4.08-4.42$ & $117-143$ & $37-52$ & 201 \\
\hline Rapeseed & $4.59-5.83$ & $94-120$ & $37.6-56$ & 194.7 \\
\hline Sunflower & $4.38-4.90$ & $110-143$ & $45-51$ & 200 \\
\hline Cotton seed & $4-9.6$ & $90-119$ & $41.2-59.5$ & 204 \\
\hline Tallow & - & 126 & 59 & $218-235$ \\
\hline
\end{tabular}

$[17,18,20]$.

Table 4 shows that the specific gravity of the synthesized biodiesel was $0.89 \pm 0.12$ which is within range of the petrodiesel and ASTM standard. Density is an important property for diesel fuel injection system, for optimal functioning of diesel fuel the density must be maintained within a set standard. According to Galadima et al. [18] high density of biodiesel can lead to incomplete combustion. The Kinematic viscosity of $2.80 \pm 0.14 \mathrm{~mm}^{2} / \mathrm{s}$ was within the range of 1.9-6.0 for the petro-diesel and the same for the ASTM. The water and sediment content of $0.025 \%$ was below the ASTM standard of $0.05 \%$. [21]. The acid number was $0.15 \mathrm{mgKOH} / \mathrm{g}$ and below that for Petrol diesel which stood at $0.8 \mathrm{mgKOH} / \mathrm{g}$. According to the work of Alkabbashi et al. [20], $0.26 \mathrm{mgKOH} / \mathrm{g}$ acid number obtained from the use of palm oil is higher than that obtained for the present study. Cetane number was 63 which is higher than that for the petrodiesel 46, this gives the biodiesel from African pear an edge because it will have a better performance in the internal combustion engine. The pour point of $-13^{\circ} \mathrm{C}$ obtained for the produced biodiesel is higher than that of petrodiesel of $-20^{\circ} \mathrm{C}$, which is a disadvantage. However pour point dispersant additive could be used to control the pour point of the synthesized biodiesel. The flashpoint of the biodiesel was far above the $93^{\circ} \mathrm{C}$ minimum by ASTM and $82^{\circ} \mathrm{C}$ for petrodiesel. The low flash point of diesel is an indication of its ability to ignite without fire outbreak. The amount of sulphur content $(0.02 \% \mathrm{~m} / \mathrm{m})$ was infinitesimal as such cannot have any effect on the environment. The diesel from the African pear had a better cetane rating than other natural seed oil as shown in table 5, though other properties were similar. Report has it that cetane number widely affects the profile of heat release and also could be responsible for the emission of pollutants and combustion noise [22]. Comparing the properties of the biodiesel with petrodiesel and ASTM standards there are few differences in the parameters checked; with that from African pears having comparative advantage. This shows that apart from producing biodiesel from African pear for use as diesel fuel alone it can also serve as a very good blend for the petrodiesel. It also shows that diesel from African pear oil can serve as an alternative to petrodiesel, when its production capacity is well managed.

\section{Conclusion}

African pear oils (mesocarp or pulp) has been found to be a promising feedstock for the production of biodiesel considering the physical and fuel properties of both the raw oil and the synthesized biodiesel were comparable with that of the petrodiesel. Also, this similar values of its properties with that of petrol diesel may boosts blending with petrol diesel. Hence, 
utilization of oil-plant biomass like $D$. edulis as a substitute for fossil fuel can lessen the ever-increasing emission of greenhouse gases linked with petro-diesel, therefore, providing a safer, cleaner and almost pollution-free world. It also revealed that African pear pulp oil can be beneficially employed for synthesis of biodiesel, thereby encourages its cultivation on an industrial scale for a sustainable and cheap source of feedstock for biodiesel production.

\section{References}

[1] Hill, J., Nelson, E., Tilman, D., Polasky, S. \& Tiffany, D. (2006). Environmental, economic, and energetic costs benefits of diesel and ethanol biofuels. Proceedings of National Academy of science, USA 103, 11206-11210.

[2] Marshall, A. T. (2007). Bioenergy from waste: A growing source of power, waste management. World magazine, April, $\mathrm{p}$ 34-37.

[3] Meher, L., Sagar, D., \& Naik S. (2006). Technical aspects of biodiesel production by transesterification: a review. Renewable and Sustainable Energy Reviews, 10, 248-268.

[4] Ogunsuyi, H. O. (2012). Acid and base catalysed transesterification of Mango (Mangifera Indica) Seed Oil to Biodiesel. IOSR Journal of Applied Chemistry, 2 (2): 18-22.

[5] Mukhtar, N. A. M., et al., (2019). "The influence of formulation ratio and emulsifying settings on tri-fuel (DieselEthanol-Biodiesel) emulsion properties. Energies 12 (9), 1708 .

[6] Mehlenbacher, V. C. (1960). The analysis of fats and oils. The Gerrard Press Limited, Illinois.

[7] Thushari, I. \& Babel, S. (2018). Sustainable utilization of waste palm oil and sulfonated carbon catalyst derived from Coconut meal residue for biodiesel production. Bioresources and Technology, 248, 199-203.

[8] Ogunsuyi HO, Daramola BM (2013). Evaluation of Almond (Prunus amygdalus) Seed Oil as Viable Feedstock for Biodiesel Fuel. International Journal of Biotechnological Research, 1 (8): 120-127.

[9] Rashid U, Farooq A, Gerhard K (2009). Evaluation of biodiesel obtained from cottonseed oil. Fuel Processing Technology, 90 (9): 1157-1163.

[10] Obasi N. B. B, Okolie NP (1993), Nutritional constituents of the seeds of African pear, Dacryodes edulis. Food Chemistry, 46 (3): 297-299.
[11] Codex Alimentarius. (1999). Codex Alimentarius Standards for Fats and oils from Vegetable Sources. Section 2. Codex alimentarius Standards for Named Vegetrable oils. Codex Alimentarius-Stan. 210.

[12] Pearson D. (1976). The chemical analysis of foods 7th Eden, Churchill Livingstone, London, 133p.

[13] Rethinam, P. (2003). New Approaches to Coconut oils and fats. African Journal of Food, Agriculture, Nutrition and Development. 19 (2): 22-25.

[14] Al-Widyan, M. L. and Al-Shyoukh, A. O. (2002). Experimental evaluation of the transesterification of waste palm oil into biodiesel. Bioresources and Technolology 85 (3): 253-256.

[15] N'guetta, A. M. N., Digbeu, D. Y., Binaté, S., Kouadio, N. E. P. J., Dabonné, S. and Dué, A. E. (2015). Fatty Acid Composition and Physicochemical Properties of Four Varieties of Citrullus lanatus Seed Oils Cultivated in Côte d'Ivoire. British Biotechnology Journal. 5 (3): 140-147.

[16] Leung, D. Y. C. and Guo, Y. (2006). Transesterification of meat and used frying oil; Optimization for biodiesel production. Fuel Process and Technology. 87: 883-890.

[17] Ibeto, C. N., Ofoefule, A. U. and Ezeugwu, H. C. (2011). Fuel Quality Assessment of Biodiesel Produced from Groundnut Oil (Arachis Hypogea) and its blend with Petroleum Diesel. American Journal of Food Technology. 6 (9): 798-803.

[18] Galadima, A., Garba, Z. N. \& Ibrahim, B. M. (2008). Homogeneous and heterogeneous transesterification of grounnut oil for synthesizing methyl biodiesel', International Journal of Pure and Applied Sciences, 2; 138-144.

[19] Ishola, F., Adelekan, D., Mamudu, A., Abodunrin, T., Aworinde, A., Olatunji, O. \& Akinlabi, S. (2020). Biodiesel production from palm olein: A sustainable bioresource for Nigeria. Heliyon, 6, 1-12.

[20] Alkabbashi, A. N., Alam, M. Z. and Mirghani, M. E. S. and Al-Fusaiel, A. M. A. (2009). Biodiesel Production from crude palm oil by transesterification process. Journal of Applied Sciences. 9: 3166-3170.

[21] US Department of Energy. (2004). Biodiesel: Handling and use guidelines. Energy Efficiency and Renewable Energy, United States Department of Energy. 667p.

[22] Giakoumis, Evangelos G. \& Sarakatsanis, Christos K., (2019). A comparative assessment of biodiesel cetane number predictive correlations based on fatty acid composition. Energies, 12 (3), 422. 